\title{
Research on the Relationship between Executive Compensation and Corporate Performance
}

\author{
Fangna Peng ${ }^{1, a^{*}}$ and Mengnong Zhou ${ }^{1, b}$ \\ ${ }^{1}$ Wuhan University of Technology, School of Management, Wuhan, 430070, P. R. China \\ apfn664@163.com, bhoumn2006@sina.com \\ * The corresponding author
}

Keywords: Executive compensation; Monetary compensation; Shareholding ratio; Corporate performance

\begin{abstract}
The paper takes a sample of A-share listed companies from 2013 to 2017 in China, and examines the effect of executive compensation on corporate performance from the perspective of Executive's monetary compensation and shareholding ratio. The results show that: Chinese listed company executives' monetary compensation, shareholding ratio and corporate performance are positively correlated, that is, the higher the company's executive monetary compensation, the better corporate performance; the higher the company's executive ratio, the better corporate performance, which shows that salary incentives have played a proper governance role in China, and the paper also proposes policy suggestions on how to improve executive compensation and promote the improvement of corporate performance.
\end{abstract}

\section{Introduction}

Separation of management rights and ownership is an obvious feature of an enterprise. This situation has brought about the problem of entrusted agency. In order to reduce agency costs and improve the operating efficiency of enterprises, executive compensation is a key factor that cannot be ignored. Then, how should the company design the compensation structure of the executive team to promote corporate performance? In response to this problem, some studies have argued that executive compensation has nothing to do with corporate performance, and that executives' fixed compensation can easily lead to executives' laziness and it is difficult to motivate their work motivation. In addition, there are also some studies that executive compensation can contribute to corporate performance to a certain extent. Therefore, it is necessary to further explore the relationship between the two. Based on the specific composition of compensatio, monetary compensation and incentive compensation are the two main parts of executive compensation. The paper starts from these two parts and studies the influence of the two on the performance of listed companies. This paper selects Chinese 2013-2017 A-share listed company as a research sample, selects executives' monetary compensation to measure monetary compensation and executives' shareholding ratios to measure incentive compensation, and uses ROA as an indicator to measure corporate performance. The paper research found that: On the one hand, executives' monetary compensation has a positive effect on corporate performance, indicating that the increase in executive compensation will help improve corporate performance. Based on this, listed companies can design better executive pay plans within the existing institutional framework. On the other hand, the executives' shareholding ratio also has a significant positive effect on ROA, which provides a certain reference for improving executive compensation incentives.

\section{Literature Review and Research Hypothesis}

There are two main types of research on the relationship between executive compensation and corporate performance. The first category is the relationship between executive monetary compensation and corporate performance. The second category is the relationship between executive shareholding ratio and corporate performance. 
The relationship between executive monetary compensation and corporate performance. Li Zengquan (2000) [1] discusses that there is no significant positive correlation between the level of monetary compensation of senior executives and the company's operating performance, and there is a significant positive correlation with the size of firms, and there are obvious regional and industry differences. Zhang Junrui (2003) [2] believes that senior executives' annual salary compensation is positively correlated with earnings per share and company size, but shows instability and shows a multiple linear relationship. McKnight (2004) [3] believes that there is a significant positive correlation between executive compensation and corporate performance. That is, the higher executive monetary compensation, the better corporate performance. Hu Wenxiu (2011) [4] applied the equation estimation and curve fitting methods to study the correlation between executive compensation levels and corporate performance of financial listed companies in Shenzhen and Shanghai. Through empirical research, she concluded that the executive monetary compensation of financial listed companies is basically irrelevant to company performance. Cao Xiaoli(2014) [5] conducted an empirical study on the relationship between executive compensation incentives and corporate performance of listed companies in China, and concluded that the executive monetary compensation of listed companies in China had a significant positive correlation with company performance. Zhang Kuan (2017) [6] took the Shanghai and Shenzhen stock markets as examples to conduct research on executive compensation and corporate performance. He found that executive monetary compensation has a significant impact on corporate performance, and there are significant differences in this effect between state-owned enterprises and private enterprises. Based on this, the paper makes the following assumptions:

H1: There is a positive correlation between executive monetary compensation and corporate performance.

The Relationship Between Executive Shareholding Ratio and Corporate Performance. Wei Gang (2000) [7] pointed out that the phenomenon of "zero shareholdings" among senior executives is relatively common, and that holding stocks has not achieved the expected incentive effect, but is merely a welfare system arrangement, and there is no significant positive correlation with company operating performance. Wu Shukun (2002) [8] conducted an empirical analysis of relevant data of listed companies, the results show that the relationship between executive ownership ratio and corporate performance is inverse U-shaped. Huang Guitian (2009) [9] found that after the management's shareholding exceeds a certain percentage, there is a negative impact on the company's performance and even the performance begins to decline. Conyon (2011) [10] studied the executive compensation and corporate governance of listed companies in China and compared them with the executive compensation in the United States, and further found positive correlations between executive ownership and corporate performance. Han Honglian (2015) [11] analyzed the correlation between executive compensation and corporate performance of listed companies and found that executive shareholding ratio to corporate performance indicators is a weak positive correlation, and believes that most companies do not implement executive shareholding management, the corporate should establish a sound executive ownership system. Wei Han (2017) [12] takes a logistics listed company as the research perspective and empirically analyzes that the proportion of corporate executives' holdings has a positive correlation with the company's performance. That is, the higher the executive's shareholding ratio, the better the corporate's performance. Based on this, the paper makes the following assumptions:

$\mathrm{H} 2$ : There is a positive correlation between the executive shareholding ratio and corporate performance.

\section{Research Design}

Sample Data and Data Sources. The paper takes the 2013-2017 Chinese A-share listed company (Shen $\mathrm{Hu}$ ) as the research object, excluding and filtering the sample according to the following criteria: (1)Remove ST and *ST samples; (2) Exclude financial listed companies samples; (3) Remove listed companies with incomplete data and eventually obtain 2620 sample data. The data of this study is mainly from the CSMAR database, and the data processing software used is Stata14. 0. 
Definition of Variables. The specific variables are described in Table 1.

Table 1 Variable description table

\begin{tabular}{|c|c|c|}
\hline Variable name & Variable code & Variable definitions \\
\hline return on total assets & ROA & net profit/total assets \\
\hline $\begin{array}{c}\text { executive monetary } \\
\text { compensation }\end{array}$ & LNPAY & $\begin{array}{c}\text { the natural logarithm of top three } \\
\text { executives' compensation }\end{array}$ \\
\hline executive shareholding ratio & CEOOWN & executive holdings/total shares \\
\hline shareholding concentration & TOP1 & $\begin{array}{c}\text { the number of shares held by the largest } \\
\text { shareholder/total shares }\end{array}$ \\
\hline business scale & SIZE & natural logarithm of total assets \\
\hline financial Leverage & LEV & liabilities/Total assets \\
\hline industry factors & INDUSTRY & virtual variable \\
\hline
\end{tabular}

In order to test whether Hypothesis 1 and Hypothesis 2 are true, the model constructed by the paper is:

$$
\begin{aligned}
& \text { ROA }=\beta_{0}+\beta_{1} \mathrm{LNPAY}+\beta_{2} \mathrm{TOPI}+\beta_{3} \mathrm{SIZE}+\beta_{4} \mathrm{LEV}+\Sigma \text { INDUSTRY } \\
& \text { ROA }=\beta_{0}+\beta_{1} \mathrm{GEOOWN}+\beta_{2} \mathrm{TOP}+\beta_{3} \mathrm{SIZE}+\beta_{4} \mathrm{LEV}+\Sigma \text { INDUSTRY }
\end{aligned}
$$

\section{Empirical Analysis}

Descriptive Statistics. The paper analyzes the maximum, minimum, mean and standard deviation of the variables designed by in the model. Firstly, the overall data from 2013 to 2017 are analyzed. See Table 2 for details.

Table 2 Variable descriptive statistics

\begin{tabular}{cccccc}
\hline Variable & Obs & Mean & Std. Dev. & Min & Max \\
\hline ROA & 2,620 & 0.060 & 0.042 & 0.003 & 0.212 \\
LNPAY & 2,620 & 14.420 & 0.692 & 12.922 & 16.403 \\
CEOOWN & 2,620 & 0.115 & 0.160 & 0.001 & 0.630 \\
TOP1 & 2,620 & 30.976 & 13.485 & 7.340 & 64.800 \\
SIZE & 2,620 & 22.073 & 1.111 & 20.111 & 25.582 \\
LEV & 2,620 & 0.374 & 0.192 & 0.043 & 0.819 \\
\hline
\end{tabular}

From Table 2, we can see that the average return on total assets is $6 \%$, the maximum is $21.2 \%$, the minimum is $0.3 \%$, and the standard deviation is 0.042 , which shows that the listed companies have a large gap and show an imbalance. As can be seen from the monetary compensation in executive compensation, the gap between executives' monetary compensation is relatively small among listed companies, while the gap between executiv shareholding ratio is relatively large, with an average shareholding ratio of $11.5 \%$, indicating that executive shareholding ratio is still relatively objective, but the gap between companies is very large. In addition, there is a large gap between the shareholding of the largest shareholder of the listed company and the debt ratio.

Correlation Analysis. The correlation analysis of this paper is shown in Table 3. From the table, it can be seen that the explanatory variables LNPAY, CEOOWN and the explained variable ROA are significantly related, and the control variables and the explained variables are significantly correlated. Because the correlation coefficient between variables is low, it is considered that there is no multicollinearity between the explanatory variables and the control variables in the model. 
Table 3 Correlation coefficient matrix

\begin{tabular}{ccccccc}
\hline & ROA & LNPAY & CEOOWN & TOP1 & SIZE & LEV \\
\hline ROA & 1 & & & & & \\
LNPAY & $0.1259^{* * *}$ & 1 & & & & \\
CEOOWN & $0.1253^{* * *}$ & $-0.1799^{* *}$ & 1 & & & \\
TOP1 & $0.0836^{* * *}$ & $-0.0557^{*}$ & $0.0960^{* *}$ & 1 & & \\
SIZE & $-0.0916^{* *}$ & $0.5582^{* *}$ & $-0.3309^{* *}$ & $-0.0580^{*}$ & 1 & \\
LEV & $-0.3438^{* *}$ & $0.2866^{*}$ & $-0.2172^{* *}$ & $0.0452^{* *}$ & $0.6285^{*}$ & 1 \\
\hline
\end{tabular}

Note: $* * *, * *$, and $*$ are significant at the levels of $1 \%, 5 \%$, and $10 \%$, respectively.

Regression Analysis. As can be seen from Table 4, the goodness-of-fit test results for the equations are general. For the model as a whole, the F-test was adopted to show that ROA and other variables have a multiple linear relationship.

Table 4 Regression analysis results

\begin{tabular}{ccc}
\hline & $\operatorname{ROA}(1)$ & $\mathrm{ROA}(2)$ \\
\hline LNPAY & $0.0114^{* * * *}$ & \\
CEOOWN & $(5.03)$ & $0.0214^{* * *}$ \\
& & $(3.74)^{* * *}$ \\
TOP1 & $0.0538^{* * *}$ & $0.0467^{* *}$ \\
& $(4.19)$ & $(3.63)^{* * *}$ \\
SIZE & $-0.00367^{* *}$ & $-0.00925^{* *}$ \\
& $(-2.46)^{* * *}$ & $(-2.19)^{* * *}$ \\
LEV & $-0.0240^{* * *}$ & $-0.0253^{* * *}$ \\
& $(-3.06)^{* *}$ & $(-3.22)^{* *}$ \\
cons & $-0.0323^{* *}$ & $-0.0317^{* *}$ \\
INDUSTRY & $(-2.41)$ & $(-2.33)$ \\
$\mathrm{N}$ & Controlled & Controlled \\
F & 2620 & 2620 \\
$\mathrm{R}^{2}$ & 27.36 & 25.45 \\
\end{tabular}

The model uses the total assets net profit rate as an indicator of corporate performance to return. From the regression results, it can be seen that there is a significant positive correlation between executive monetary compensation and firm performance, which verifies the hypothesis 1 of this paper. There is also a significant positive correlation between the proportion of executive holdings and corporate performance, which verifies the hypothesis 2 of this paper. In summary, there is a significant positive correlation between the executive monetary compensation and corporate performance. There is a significant positive correlation between the executive shareholding ratio and corporate performance, too. That is, to a certain extent, the higher the monetary compensation and shareholding ratio of the senior executives, the more helpful the promotion for corporate performance. [13]

\section{Conclusion}

This paper takes the A-share listed companies in Shanghai and Shenzhen in 2013-2017 as the research object, and empirically analyzes the relationship between executives' monetary compensation, the proportion of executive holdings and corporate performance, and draws the following conclusions:

(1) There is a positive correlation between executive monetary compensation and corporate performance. It shows that listed companies can design a better executive compensation plan to a certain extent based on the existing system. 
(2) There is a positive correlation between the shareholding ratio of senior executives and corporate performance. Therefore, executive incentives should be allowed to play a role in enhancing corporate performance.

The proposals presented here are as follows: When designing the compensation plan, the listed company in China should consider the compensation plan of the executive from an overall perspective. It should not only pay attention to monetary compensation, but also make equity incentives work, that is, properly consider the issue of executive's shareholding. Giving a certain amount of equity incentives will help motivate executives' motivation and resolve agent conflicts to a certain extent, thereby improving corporate performance. There are many deficiencies in this paper: the choice of variables is not adequate and appropriate, and there is incompleteness in the selection of indicators. For example, using only the total asset net profit rate represents corporate performance, which may affect the research conclusions.

\section{References}

[1] Z. Q. Li: Accounting Research, Vol. 21 (2000) No. 1, p. 24. (In Chinese)

[2] J. R. Zhang, J. W. Zhao and J. Zhang: Accounting Research, Vol. 24 (2003) No. 9, p. 29. (In Chinese)

[3] P. McKnight and C. Tomkinsb: European Management Journal, Vol. 22 (2004) No. 1, p. 27.

[4] W. X. Hu and Q. B. Mu: Management Review, Vol. 23 (2011) No. 10, p. 118. (In Chinese)

[5] X. L. Cao and M. Yang: Friends of Accounting, Vol. 32 (2014) No. 7, p. 79. (In Chinese)

[6] K. Zhang and X. Xu: Finance Economy, Vol. 36 (2017) No. 20, p. 106. (In Chinese)

[7] G. Wei: Economic Research Journal, Vol. 46 (2000) No. 3, p. 32. (In Chinese)

[8] S. K. Wu: China Industrial Economics, Vol. 20 (2002) No. 1, p. 80. (In Chinese)

[9] G. T. Huang and Y. Zhang: Economic Science, Vol. 31 (2009) No. 4, p. 86. (In Chinese)

[10] M. J. Conyon and L. R. He: Journal of Corporate Finance, Vol. 17 (2011) No. 4, p. 1158.

[11] H. L. Han and M. Zhang: Enterprise Economy, Vol. 34 (2015) No. 3, p. 149. (In Chinese)

[12] H. Wei: Guangdong Economy, Vol. 26 (2017) No. 16, p. 4. (In Chinese)

[13] Z. G. Li: Modern Management Science, Vol. 34 (2015) No. 3, p. 106. (In Chinese) 